\title{
HUBUNGAN ANTARA SUMBER INFORMASI, PENGETAHUAN DAN PERILAKU IBU DENGAN KEJADIAN PNEUMONIA PADA BALITA DI WILAYAH PUSKESMAS KRAMATWATU KABUPATEN SERANG TAHUN 2017
}

\author{
Jumiati, Umalihayati * \\ Akademi Kebidanan `Aisyiyah Banten \\ Email: jumiatiisro@gmail.com umalihayatikuru@gmail.com
}

\begin{abstract}
Abstrak
Pneumonia masih merupakan masalah kesehatan masyarakat di Indonesia terutama pada Balita. Menurut sumber Ditjen P2P Kemenkes RI tahun 2017 ditemukan jumlah kasus Pneumonia pada Balita sebesar 57,84\% atau 503.738 Balita dari target penemuan kasus pneumonia pada balita sebanyak 870.893 orang, sedangkan di Propinsi Banten ditemukan jumlah kasus Pneumonia pada Balita sebesar 57,84\% atau 503.738 Balita dari target penemuan kasus pneumonia pada balita sebanyak 870.893 orang. Tahun 2015 di Puskesmas Kramatwatu ditemukan balita dengan pneumonia sebanyak 1.725 balita $(19,4 \%)$ dari jumlah keseluruhan balita yaitu 8.894 jiwa Balita dan dan yang mendapatkan penanganan kasus sebesar 438 balita $(25,4 \%)$.

Tujuan penelitian ini adalah untuk mengetahui Perilaku hidup sehat ibu yang menjadi faktor dominan terhadap resiko kejadian ISPA Pneumonia pada Balita di Wilayah Puskesmas Kramatwatu Kabupaten Serang Tahun 2016.

Metode Penelitian Jenis penelitian ini adalah observational analytic dengan rancangan penelitian case control study. Populasi dalam penelitian ini adalah seluruh balita yang berada di wilayah kerja Puskesmas Kramatwatu Kabupaten Serang Tahun 2016. Sampel penelitian ini terdiri dari kelompok kasus 110 dengan balita yang menderita ISPA Pneumonia dan kelompok control 110 Balita yang tidak menderita ISPA Pneumonia. Uji coba instrumen penelitian dilakukan untuk menguji validitas dan reliabilitas kuisioner dengan menggunakan rumus korelasi product moment. Pengolahan data dilakukan dengan cara Editing, scoring, coding dan Tabulating dengan menggunakan analisa data univariat, bivariat dan multivariat.

Hasil Penelitian Univariat didapatkan Balita yang mengalami Pneumonia 48,4\% , ibu dengan pengetahuan yang rendah $24,2 \%$, ibu yang belum terpapar informasi tentang Pneumonia $32,6 \%$ dan Ibu yang memiliki Perilaku tidak sehat 41,1\%. Sedangkan analisis Bivariat diperoleh hasil bahwa ada hubungan antara Sumber Informasi, Pengetahuan, Perilaku Ibu dengan Kejadian Pneumonia pada Balita di wilayah Puskesmas Kramatwatu Kabupaten Serang Tahun 2017.

Saran yang dapat disampaikan untuk menurunkan angka kejadian Pneumonia pada Balita yaitu memberikan informasi tentang penyakit Pneumonia pada Balita melalui penyuluhan di Posyandu, Puskesmas ,Pengajian atau kegiatan lain yang ada di masyarakat.
\end{abstract}

Kata Kunci : Sumber informasi, pengetahuan, perilaku ibu, kejadian pneumonia 


\section{PENDAHULUAN}

Pneumonia pula masih merupakan masalah kesehatan masyarakat di Indonesia terutama pada Balita. Menurut sumber Ditjen P2P Kemenkes RI tahun 2017 ditemukan jumlah kasus Pneumonia pada Balita sebesar $57,84 \%$ atau 503.738 Balita dari seluruh jumlah target penemuan kasus pneumonia pada balita sebanyak 870.893 orang.

Penyakit ini dapat menimbulkan berbagai sprektrum penyakit dari penyakit tanpa gejala sampai penyakit parah dan mematikan, tergantung pada pathogen penyebabnya, faktor lingkungan dan pejamu. Berdasarkan sumber Ditjen P2P Kemenkes RI tahun 2017 untuk Wilayah Propinsi Banten ditemukan kasus pneumonia pada Balita Tahun 2016 sebesar $59,41 \%$ atau 24.908 Balita dari jumlah target penemuan kasus pneumonia pada Balita sebanyak 41.927 orang. Dinas Kesehatan Kabupaten Serang dalam kasus pneumonia pada balita tahun 2012 jumlah Balita 175.948 jiwa, kasus pneumonia yang ditemukan sebanyak 17.599 balita (10\%) sedangkan yang ditangani sebanyak 2.996 balita (17\%). Puskesmas Kramatwatu Tahun 2015 ditemukan balita dengan pneumonia sebanyak 1.725 balita (19.4\%) dari jumlah keseluruhan balita di Puskesmas Kramatwatu yaitu 8.894 jiwa Balita, dan yang mendapatkan penanganan kasus sebesar 438 balita (25,4\%). (Profil Puskesmas Kramatwatu, 2015).

Penyakit Infeksi Saluran Pernafasan Akut(ISPA) sering terjadi pada anak Balita, karena sistem pertahanan tubuh anak masih rendah. Kejadian batuk pilek pada balita di Indonesia diperkirakan 3 sampai 6 kali setahun. Penyakit ISPA dapat ditularkan melalui air ludah, bersin, udara pernafasan yang mengandung kuman yang terhirup oleh orang sehat ke saluran pernafasannya. Pneumonia adalah proses infeksi akut yag mengenai jaringan paru - paru (alveoli). Terjadinya pneumonia pada anak sering kali bersamaan dengan terjadinya infeksi akut pada bronchus yang disebut Brokhopneumonia. Dalam pelaksanaan pengendalian penyakit ISPA semua bentuk pneumonia (baik pneumonia maupun bronchopneumonia), di sebut Pneumonia saja (DepKes 2006).

Hasil penelitian Siti Sundari,dkk (2013) didapatkan bahwa $66.67 \%$ terdapat pada umur anak 1 - 5 tahun serta perempuan lebih banyak terserang ISPA Pneumonia $54,17 \%$, Tingkat pendidikan ibu Balita kelompok kasus dan kelompok kontrol sebagian besar dalam kategori menengah (SMP \& SMA), namun tingkat pendidikan tinggi lebih besar pada kelompok kontrol dan tingkat pendidikan rendah lebih pada kelompok kasus, proporsi tidak bekerja lebih besar pada kelompok kasus, perilaku pemeliharaan kesehatan tidak sehat yang 
dilakukan ibu yang memiliki risiko terjadinya pneumonia pada balita dimulai dari yang paling dominan meliputi kebiasaan ibu tidak menutup hidung dan mulut ketika batuk, perilaku ibu tidak sehat tentang penggunaan fasilitas pelayanan kesehatan adalah ibu tidak segera membawa berobat ke fasilitas kesehatan apabila balitanya sakit ISPA yang disertai dengan gejala Pneumonia, perilaku kesehatan lingkungan tidak sehat yang dilakukan oleh ibu balita adalah tidak membuka jendela kamar tidur setiap hari, merokok tidak membuka jendela ruang keluarga, perilaku merokok dalam rumah.

Berdasarkan latar belakang diatas, peneliti sangat tertarik untuk mengambil penelitian ilmiah dengan judul "Hubungan antara sumber informasi, pengetahuan dan prilaku ibu dengan kejadian Pneumonia pada Balita di Wilayah Kerja Puskesmas Kramatwatu Kabupaten Serang Tahun 2017”.

\section{Metoda}

Desain penelitian yang digunakan dalam penelitian ini adalah cross sectionl. Populasi dalam penelitian ini adalah seluruh balita yang berada di wilayah Puskesmas Kramatwatu Kabupaten Serang tahun 2016 yaitu sebanyak 1725 Balita. sampel yang diperlukan adalah sebanyak 95 Responden.

Teknik pengambilan sampel yang akan dijadikan subjek penelitian dengan menggunakan teknik berupa accidental sampling. Alat pengumpulan data yang digunakan dalam penelitian ini adalah lembar ceklis kuesioner yang dibagikan pada ibu yang memiliki balita. Metode pengumpulan data dengan membagikan lembar ceklis kuesioner pada para ibu yang memiliki balita untuk diisi yang terdiri dari beberapa pertanyaan. Data yang diambil adalah data primer yang didapat atau bersumber dari ibu yang memiliki balita yang kebetulan atau berkunjung ke Puskesmas Kramatwatu Kabupaten Serang Tahun 2017

\section{Hasil}

Univariat Tabel 4.1

Distribusi Kejadian Pneumonia pada Balita di Puskesmas Kramatwatu Tahun 2017

\begin{tabular}{|c|c|c|}
\hline Pneumonia & Frekuensi & Presentase \\
\hline $\mathrm{Ya}$ & 46 & 48.4 \\
\hline Tidak & 49 & 51.6 \\
\hline Total & 95 & 100 \\
\hline
\end{tabular}

Tabel 4.1 menunjukkan bahwa hampir separuhnya $48.4 \%$ Balita menderita penyakit Pneumonia

Tabel 4.2

Distribusi Sumber Informasi tentang Pneumonia di Puskesmas Kramatwatu Tahun 2017

\begin{tabular}{ccc}
\hline $\begin{array}{c}\text { Sumber } \\
\text { Informasi }\end{array}$ & Frekuensi & Presentase \\
\hline $\begin{array}{c}\text { Tidak } \\
\text { pernah }\end{array}$ & 31 & 32.6 \\
\hline Pernah & 64 & 67.4 \\
\hline Total & 95 & 100 \\
\hline
\end{tabular}


Tabel 4.2 menunjukkan bahwa masih ditemukannya $32,6 \%$ Ibu belum pernah mendapatkan informasi tentang Pneumonia

Tabel 4.3

Distribusi Pengetahuan Ibu yang memiliki Balita tentang Pneumonia di Puskesmas Kramatwatu Tahun 2017

\begin{tabular}{ccc}
\hline Pengetahuan & Frekuensi & Presentase \\
\hline Rendah & 23 & 24.2 \\
\hline Tinggi & 72 & 75.8 \\
\hline Total & 95 & 100 \\
\hline
\end{tabular}

Tabel 4.3 menunjukkan bahwa masih ditemukannya $24,2 \%$ ibu yang memiliki Balita berpengetahuan rendah tentang Pneumonia

Tabel 4.4

Distribusi Perilaku Ibu di Puskesmas Kramatwatu Tahun 2017

\begin{tabular}{ccc}
\hline $\begin{array}{c}\text { Perilaku } \\
\text { Ibu }\end{array}$ & Frekuensi & Presentase \\
\hline $\begin{array}{c}\text { Tidak } \\
\text { Sehat }\end{array}$ & 39 & 41.1 \\
\hline Sehat & 56 & 58.9 \\
\hline Total & 95 & 100 \\
\hline
\end{tabular}

Tabel 4.4 menunjukkan bahwa hampir setenaghnya $41.1 \%$ Ibu memiliki prilaku tidak sehat

Analisis Bivariat

Tabel 4.5

Hubungan Sumber Informasi dengan

Kejadian Pneumonia pada Balita di

Puskesmas Kramatwatu Tahun 2017

\begin{tabular}{cccccc}
\hline $\begin{array}{c}\text { Sumber } \\
\text { Informa }\end{array}$ & \multicolumn{2}{c}{ Kejadian } & Total & Nilai & OR \\
si & Ya & Tidak & & V & \\
\cline { 1 - 4 } Tidak & 26 & 5 & 31 & 0.000 & 11.440 \\
Pernah & $83.9 \%$ & $16.1 \%$ & $100 \%$ & & $(3.833-$ \\
\cline { 1 - 3 } Pernah & 20 & 44 & 64 & & $34.140)$ \\
& $31.2 \%$ & $68.8 \%$ & $100 \%$ & & \\
\cline { 1 - 3 } Total & 46 & 49 & 95 & & \\
& $48.4 \%$ & $51.6 \%$ & $100 \%$ & & \\
\hline
\end{tabular}

Tabel 4.5 menunjukkan bahwa ibu yang tidak pernah mendapatkan informasi tentang pneumonia proporsi lebih tinggi untuk terjadinya pneumonia pada Balita yaitu $83,9 \%$ dibandingkan dengan ibu yang pernah mendapatkan informasi $48.4 \%$.

Hasil uji statistic diperoleh nilai $\mathrm{p}$ value $0.000(\mathrm{p}<0.005)$ yang berarti Ho ditolak, artinya bahwa terdapat hubungan yang bermakna antara sumber informasi dengan kejadian pneumonia pada balita di Puskesmas Kramatwatu Tahun 2017. Selain itu diperoleh nilai OR sebesar 11.440 yang artinya bahwa ibu yang tidak mendapatkan informasi tentang pneumonia beresiko 11 kali lebih besar untuk terjadinya pneumonia pada Balita dibandingkan dengan ibu yang pernah mendapatkan informasi

\section{Tabel 4.6}

Hubungan Pengetahuan Ibu dengan Kejadian Pneumonia pada Balita di Puskesmas Kramatwatu Tahun 2017

\begin{tabular}{|c|c|c|c|c|}
\hline Pengetahuan & $\begin{array}{c}\text { Kejadian } \\
\text { Pneumonia }\end{array}$ & Total & $\begin{array}{c}\text { Nilai } \\
\text { P Value }\end{array}$ & OR \\
\hline & Ya Tidak & & & \\
\hline Rendah & $\begin{array}{cc}17 & 6 \\
73.9 \% & 26.1 \%\end{array}$ & $\begin{array}{c}23 \\
100 \%\end{array}$ & 0.010 & $\begin{array}{c}4.201 \\
(1.480-\end{array}$ \\
\hline Tinggi & $\begin{array}{cc}29 & 43 \\
40.3 \% & 59.7 \%\end{array}$ & $\begin{array}{c}72 \\
100 \%\end{array}$ & & 11.923) \\
\hline Total & $\begin{array}{cc}46 & 49 \\
48.4 \% & 51.6 \%\end{array}$ & $\begin{array}{c}95 \\
100 \%\end{array}$ & & \\
\hline
\end{tabular}

Tabel 4.6 menunujukkan bahwa Ibu dengan pengetahuan rendah tentang pneumonia proporsi lebih tinggi untuk terjadi pneumonia pada Balita yaitu $73.9 \%$ dibandingkan dengan Ibu yang berpengetahuan tinggi $48.4 \%$.

Hasil uji statistic diperoleh nilai $\mathrm{p}$ value sebesar $0.010(\mathrm{p}<0.005)$ yang berarti Ho ditolak, artinya bahwa terdapat hubungan 
yang bermakna antara pengetahuan dengan kejadian pneumonia pada balita di Puskesmas Kramatwatu Tahun 2017. Selain itu diperoleh nilai OR sebesar 4.201 yang artinya bahwa ibu yang berpengetahuan rendah tentang pneumonia beresiko 4 kali untuk terjadi pneumonia pada Balita dibandingkan dengan ibu yang berpengetahuan tinggi.

\section{Tabel 4.7}

Hubungan Perilaku Ibu dengan Kejadian Pneumonia pada Balita di Puskesmas

\begin{tabular}{|c|c|c|c|c|c|}
\hline \multicolumn{6}{|c|}{ Kramatwatu Tahun 2017} \\
\hline \multirow{3}{*}{$\begin{array}{l}\text { Perilaku } \\
\text { Ibu }\end{array}$} & \multirow{2}{*}{\multicolumn{2}{|c|}{$\begin{array}{c}\text { Kejadian } \\
\text { Pneumonia }\end{array}$}} & \multirow[t]{3}{*}{ Total } & \multirow{3}{*}{\multicolumn{2}{|c|}{$\begin{array}{c}\text { Nilai } \\
\mathrm{P} \\
\text { Value }\end{array}$}} \\
\hline & & & & & \\
\hline & Ya & Tidak & & & \\
\hline Tidak & 32 & 7 & 39 & 0.000 & $13.714(4.95$ \\
\hline Sehat & $82.1 \%$ & $17.9 \%$ & $100 \%$ & & $-37.926)$ \\
\hline \multirow[t]{2}{*}{ Sehat } & 14 & 42 & 56 & & \\
\hline & $25 \%$ & $75 \%$ & $100 \%$ & & \\
\hline \multirow[t]{2}{*}{ Total } & 46 & 49 & 95 & & \\
\hline & $48.4 \%$ & $51.6 \%$ & $100 \%$ & & \\
\hline
\end{tabular}

Tabel 4.7 menunjukkan bahwa ibu yang berperilaku tidak sehat proporsi lebih tinggi untuk terjadinya pneumonia pada Balita yaitu $82.1 \%$ dibandingkan dengan ibu yang berperilaku sehat $25 \%$.

Hasil uji statistic diperoleh nilai $\mathrm{p}$ value 0.000 ( $\mathrm{p}<0.005$ ) yang berarti Ho ditolak, artinya bahwa terdapat hubungan yang bermakna antara perilaku ibu dengan kejadian pneumonia pada Balita di Puskesmas Kramatwatu Tahun 2017. Selain itu diperoleh nilai OR sebesar 13.714 yang artinya bahwa ibu yang berperilaku tidak sehat dalam pengasuhan anaknya beresiko 14 kali lebih besar untuk terjadinya pneumonia pada Balita dibandingkan dengan ibu yang berperilaku sehat.

\section{Pembahasan}

Kejadian Pneumonia pada Balita

Hasil penelitian yang sudah dilakukan didapatkan bahwa hampir setengahnya 46 (48.4\%) Ibu yang memiliki Balita terserang Pneumonia di Puskesmas Kramatwatu tahun 2017. Kejadian peumonia pada Balita berdasarkan hasil penelitian didukung juga oleh ibu yang perilaku tidak sehat, pengetahuan serta sumber informasi yang belum di dapat hampir setengahnya yang diperoleh oleh responden. Menurut informasi yang didapatkan berdasarkan wawancara dengan responden, banyak responden yang belum terpapar dengan informasi tentang pneumonia sehingga pengetahuan mereka tentang pneumonia kurang yang mengakibatkan perilaku responden tidak sehat.

Hasil penelitian ini hampir sama kejadiannya dengan data Propinsi Banten Tahun 2016 yaitu 59,41\% kasus penemuan Pneumonia pada Balita dan data Indonesia Tahun 2016 ditemukan kasus kejadian Pneumonia pada Balita sebesar 57,84\% (Data Ditjen P2P Kemenkes RI).

Wilayah Puskesmas Kramatwatu, dan ini sangat dibutuhkan dukungan serta kerjasama Tenaga Kesehatan untuk lebih menggerakkan dalam memberikan penyuluhan tentang penyakit pneumonia 
baik melalui posyandu, pengajian maupun kegiatan yang ada di masyarakat.

Hasil penelitian ini sesuai dengan teori Notoadmojo (2010) yang mengatakan bahwa Pengetahuan atau kognitif merupakan domain yang sangat penting untuk terbentuknya tindakan seseorang (over behavior), pengetahuan dapat diperoleh melalui pengalaman sendiri dan orang lain. Dari pengalaman dan penelitian terbukti bahwa perilakunya yang didasari oleh pengetahuan akan lebih baik dari pada perilaku yang tidak didasari oleh pengetahuan.

Hasil analisa bivariat pada penelitian ini sama dengan hasil penelitian yang sudah dilalukan oleh Hajar Ibnu (2013) yang menunjukkan bahwa secara statistik terdapat hubungan yang bermakna antara pengetahuan ibu dengan kejadian Pneumonia pada Balita.

Berdasarkan informasi yang diperoleh pada saat wawancara, masyarakat masih banyak yang belum terpapar informasi tentang pneumonia sehingga bagaimana cara mengenali penyakit pneumonia sampai dengan ke tindakan pencegahan dan penanganan, masyarakat belum tahu.

\section{Hubungan Sumber Informasi dengan kejadian pneumonia pada Balita di Puskesmas Kramatwatu Kabupaten Serang Tahun 2017}

Hasil penelitian didapatkan bahwa ibu yang tidak pernah mendapatkan informasi tentang pneumonia proporsi lebih tinggi untuk terjadinya pneumonia pada Balita yaitu 83,9\% dibandingkan dengan ibu yang pernah mendapatkan informasi $48.4 \%$. Hasil uji statistic diperoleh nilai $\mathrm{p}$ value $0.000(\mathrm{p}<0.005)$ yang berarti Ho ditolak, artinya bahwa terdapat hubungan yang bermakna antara sumber informasi dengan kejadian pneumonia pada balita di Puskesmas Kramatwatu Tahun 2017. Selain itu diperoleh nilai OR sebesar 11.440 yang artinya bahwa ibu yang tidak mendapatkan informasi tentang pneumonia beresiko 11 kali untuk terjadinya pneumonia pada Balita dibandingkan dengan ibu yang pernah mendapatkan informasi.

Hasil penelitian ini sesuai dengan teori Rahmayani (2010) yang mengatakan bahwa Sumber informasi akan mempengaruhi bertambahnya seseorang tentang suatu hal sehingga informasi yang diperoleh dapat terkumpul secara keseluruhan ataupun sebagian, serta di perkuat oleh teori Jogianto yang berpendapat bahwa Informasi yang berkualitas tergantung dari tiga hal yaitu : Akurat yang artinya informasi harus bebas dari kesalahan-kesalahan dan harus jelas mencerminkan hasilnya, Tepat pada waktunya yang artinya informasi yang diterima tidak boleh terlambat dan Relavan yang artinya informasi tersebut mempunyai manfaat oleh pemakainya. 
Penelitian ini sama hasilnya dengan penelitian yang dilakukan di Puskesmas Ciputat yang menunjukkan bahwa ada hubungan bermakna antara sumber informasi dengan kejadian pneumonia pada Balita.

Dari hasil penelitian dapat disimpulkan oleh peneliti bahwasannya sangatlah penting sekali keterpaparan informasi tentang penyakit pneumonia pada balita yang harus diketahui oleh ibunya sehingga pengetahuan yang didapat oleh ibu yang memiliki balita dapat sebagai factor protectif terhadap kejadian pneumonia pada Balita.

2. Hubungan Pengetahuan dengan kejadian pneumonia pada balita di Puskesmas Kramatwatu Kabupaten Serang Tahun 2017

Hasil penelitian didapatkan bahwa Ibu dengan pengetahuan rendah tentang pneumonia proporsi lebih tinggi untuk terjadi pneumonia pada Balita yaitu $73.9 \%$ dibandingkan dengan Ibu yang berpengetahuan tinggi 48.4\%. Hasil uji statistic diperoleh nilai $\mathrm{p}$ value sebesar 0.010 ( $\mathrm{p}<0.005$ ) yang berarti Ho ditolak, artinya bahwa terdapat hubungan yang bermakna antara pengetahuan dengan kejadian pneumonia pada balita di Puskesmas Kramatwatu Tahun 2017. Selain itu diperoleh nilai OR sebesar 4.201 yang artinya bahwa ibu yang berpengetahuan rendah tentang pneumonia beresiko 4 kali untuk terjadi pneumonia pada Balita dibandingkan dengan ibu yang berpengetahuan tinggi.

Dari hasil penelitian yang kami dapatkan berdasarkan kuesioner yang diisi oleh responden, pengetahuan yang sangat rendah yaitu tentang bagaimana cara penularan penyakit pneumonia dapat di jawab dengan benar oleh responen hanya 55 $\%$. Hal ini membuktikan bahwa kurangnya informasi tentang penyakit pneumonia oleh ibu yang memiliki balita di wilayah Puskesmas Kramatwatu, dan ini sangat dibutuhkan dukungan serta kerjasama Tenaga Kesehatan untuk lebih menggerakkan dalam memberikan penyuluhan tentang penyakit pneumonia baik melalui posyandu, pengajian maupun kegiatan yang ada di masyarakat.

Hasil penelitian ini sesuai dengan teori Notoadmojo (2010) yang mengatakan bahwa Pengetahuan atau kognitif merupakan domain yang sangat penting untuk terbentuknya tindakan seseorang (over behavior), pengetahuan dapat diperoleh melalui pengalaman sendiri dan orang lain. Dari pengalaman dan penelitian terbukti bahwa perilakunya yang didasari oleh pengetahuan akan lebih baik dari pada perilaku yang tidak didasari oleh pengetahuan.

Hasil analisa bivariat pada penelitian ini sama dengan hasil penelitian yang sudah dilalukan oleh Hajar Ibnu (2013) yang 
menunjukkan bahwa secara statistik terdapat hubungan yang bermakna antara pengetahuan ibu dengan kejadian Pneumonia pada Balita.

Berdasarkan informasi yang diperoleh pada saat wawancara, masyarakat masih banyak yang belum terpapar informasi tentang pneumonia sehingga bagaimana cara mengenali penyakit pneumonia sampai dengan ke tindakan pencegahan dan penanganan, masyarakat belum tahu.

\section{Hubungan Perilaku Ibu dengan Kejadian Pneumonia pada Balita di Puskesmas Kramatwatu Kabupaten Serang Tahun 2017.}

Hasil penelitian didapatkan bahwa ibu yang berperilaku tidak sehat proporsi lebih tinggi untuk terjadinya pneumonia pada Balita yaitu $82.1 \%$ dibandingkan dengan ibu yang berperilaku sehat $25 \%$. Hasil uji statistic diperoleh nilai $\mathrm{p}$ value 0.000 ( $\mathrm{p}<0.005)$ yang berarti Ho ditolak, artinya bahwa terdapat hubungan yang bermakna antara perilaku ibu dengan kejadian pneumonia pada Balita di Puskesmas Kramatwatu Tahun 2017. Selain itu diperoleh nilai OR sebesar 13.714 yang artinya bahwa ibu yang berperilaku tidak sehat beresiko 14 kali untuk terjadinya pneumonia pada Balita dibandingkan dengan ibu yang berperilaku sehat.

Hasil penelitian yang kami dapatkan berdasarkan kuesioner yang diisi oleh responden didapatkan bahwa masih banyak anggota keluarga yaitu $77 \%$ merokok didalam rumah dan ibu yang tidak menggunakan masker atau menutup hidung dan mulut ketika kontak dengan anaknya dan hampir setengahnya ibu yang memiliki balita jarang membuka jendela rumah ketika pagi hari serta tidak memberika imunisasi lengkap pada anaknya.

Hasil penelitian ini sesuai dengan teori Notoadmojo yang mengatakan bahwa Perilaku kesehatan merupakan aktivitas atau kegiatan seseorang, baik yang dapat diamati (observable) maupun yang tidak dapat diamati (unobservable), yang berkaitan dengan pemeliharaan dan peningkatan kesehatan, serta didukung juga oleh teori Becker yang mengatakan bahwa Perilaku atau gaya hidup positif untuk kesehatan yaitu tindakan atau perilaku seseorang agar dapat terhindar dari berbagai macam penyakit dan masalah kesehatan, termasuk perilaku untuk meningkatkan kesehatan.

Hasil peneilitian ini sama dengan penelitian yang dilakukan oleh Putri Ika (2015) yang meunjukkan bahwa ada hubungan yang bermakna antara perilaku ibu dengan kejadian pneumonia pada Balita.

\section{Simpulan}

Hasil Penelitian Univariat didapatkan Balita yang mengalami Pneumonia 48,4\% , ibu dengan pengetahuan yang rendah $24,2 \%$, ibu yang belum terpapar informasi tentang Pneumonia 32,6\% dan Ibu yang 
memiliki Perilaku tidak sehat $41,1 \%$. Sedangkan analisis Bivariat diperoleh hasil bahwa ada hubungan antara Sumber Informasi, Pengetahuan, Perilaku Ibu dengan Kejadian Pneumonia pada Balita di wilayah Puskesmas Kramatwatu Kabupaten Serang Tahun 2017.

\section{Daftar Pustaka}

, SDKI, 2012 Profil Kesehatan

Indonesia

, 2015. Profil Puskesmas

Kramatwatu Jaya

Depkes RI, 2006. Pedoman Pengendalian Penyakit Infeksi Saluran Pernafasan Akut, Untuk Penanggulangan Pneumonia pada Balita

Hatimah, Ihat, dkk, 2007, Penelitian Pendidikan, Bandung, UPI PRESS, Bandung.

Howie, et al. 2016. Childhood pneumonia and crowding, bed-sharing and nutrition: a case-control study from The Gambia. INT J

TUBERC LUNG DIS 20(10):1405-1415.

Notoadmojo, S. 2007. Promosi Kesehatan dan Ilmu Perilaku. Jakarta. Renika Cipta

Notoatmodjo, S. (2012). Metodologi Penelitian Kesehatan (Ed.
Revisi.). Jakarta: Rineka Cipta. pp. 171-87.

Notoatmodjo, Soekidjo, 2005, Metodelogogi Penelitian Kesehatan, Rineka Cipta, Edisi Revisi, Jakarta.

Novita Aris Pramudiyani, Galuh Nita Prameswari (2010). "Hubungan antara sanitasi rumah dan perilaku dengan Kejadian pneumonia balita”. Jurnal.unnes.ac.id.

Rakhmat, Cece, 2006, Pengukuran dan Penilaian Hasil Belajar, CV. Andira, Bandung.

Ratna Sulistyowati (2010), “Hubungan Antara Rumah Tangga Sehat Dengan Kejadian Pneumonia Padabalita Di Kabupaten Trenggalek". http://uns.ac.id

Sastroasmoro, S \& Ismael, S. (2011). Dasar-dasar Metodelogi Penelitian Klinis, Ed.4. Yogyakarta: CV. Sagung Seto. pp. 104-27. ISBN: 978-6028674-54-6.

Sundari,S, Pratiwi, Khairudin. 2013 "Perilaku Tidak Sehat Ibu yang Menjadi Faktor Resiko Terjadinya ISPA Pneumonia pada Balita”.di http://jurnal.um.ac.id/index.php/j ps/ISSN :2338-9117 
Tulus Aji Yuwono (2008),Faktor-Faktor

Lingkungan Fisik Rumah yang

Berhubungan dengan Kejadian

Pneumonia pada Anak Balita di

Wilayah Kerja Puskesmas

Kawunganten Kabupaten

Cilacap 2008. http://undip.ac.id.

Ginting M (2015), Hubungan pengetahuan,

Motivasi ibu dan pendapatan

Keluarga dengan Pencegahan

Pneumonia pada Balita di

Wilayah Puskesmas Payo

Selincah Kota Jambi, Scienttia

Jurnal 